\title{
Management, production, and nutritional characteristics of cup-plant (Silphium perfoliatum) in temperate climates of southern Chile
}

\author{
Gastón Pichard
}

Departamento de Ciencias Animales, Facultad de Agronomía e Ingeniería Forestal, Pontificia Universidad Católica de Chile, Av. Vicuña Mackenna 4860, Casilla 306, Santiago 22 Chile.

\begin{abstract}
G. Pichard. 2012. Management, production, and nutritional characteristics of cup-plant (Silphium perfoliatum) in temperate climates of southern Chile. Cien. Inv. Agr. 39(1): 61-77. There is little information known about the response of cup-plant (Silphium perfoliatum L.), a perennial forage crop introduced to Chile, to differing cultivation practices. A series of studies was conducted to evaluate the adaptation and productivity of cup-plant across a range of plant densities (104,000 - 208,000 plants ha ${ }^{-1}$ ), cutting stages (early vegetative to seed formation), and different levels of $\mathrm{N}\left(0-400 \mathrm{~kg} \mathrm{~N}^{-1}\right)$ and $\mathrm{P}\left(0-400 \mathrm{~kg} \mathrm{P}_{2} \mathrm{O}_{5} \mathrm{ha}^{-1}\right)$ fertilization. Field experiments $\left(40^{\circ} \mathrm{S}\right.$ $73^{\circ} \mathrm{W}$ ) were conducted over a 3 -yr period in a subhumid, Mediterranean climate on three distinct andisols that originated from volcanic ash, with $\mathrm{pH}$ values of 5.2 to 5.6. The forage dry matter yield, plant components (stem count, stem diameter, plant height, and leaf:stem ratio), and nutritional characteristics (crude protein, plant cell wall components, and in vitro dry matter digestibility) were determined. During the first year of growth, cup-plant exhibits a rosette growth habit; the measurements were begun the second spring after planting and were taken during two consecutive growing seasons. Plant density over 120,000 plants ha ${ }^{-1}$ did not affect dry matter yield, which ranged from 15 to $20 \mathrm{tha}^{-1}$. Stem number and thickness did vary due to plant density, but height and leaf:stem ratio were not affected by density. The leaf proportion of the plants varied between 30 and $45 \%$ in the different experiments. In the cutting regime study, lower forage yields but higher nutritional values were observed with earlier first cuts. When the first cut was delayed from the early vegetative stage to the seed stage, crude protein declined from 140 to $60 \mathrm{~g} \mathrm{~kg}^{-1}$ and digestibility from 790 to $580 \mathrm{~g} \mathrm{~kg}^{-1}$, mainly due to the low nutritional value of the stems. The dry matter yield and crude protein increased with increasing levels of $\mathrm{N}$ and $\mathrm{P}$ fertilization. Cup-plant requires and absorbs low quantities of nitrogen, what renders it to be a low protein forage resource. At seemingly low rates of nitrogen fertilization, it is an efficient biomass factory. It was concluded that cup-plant can be incorporated as a regular perennial summer fodder crop and also as a special feeding resource during summer drought as a supplement to existing pasture areas when its availability becomes limited. Its adaptive and productive characteristics also make it suitable for low-input farming systems.
\end{abstract}

Key words: Cup-plant, cutting frequency, fertilization, forage crop, nutritional quality, population density.

\section{Introduction}

Cup-plant is a newly introduced forage crop, and there is limited information about its productive characteristics in the Southern Hemisphere. The

Received December 30, 2010. Accepted January 23, 2011. Corresponding author: gpichard@uc.cl plant belongs to the Heliantheae tribe of the Asteraceae family, is native to eastern North America, and was introduced to Europe and Russia as a forage crop in the late nineteenth century (Demarquilly and Niqueux, 1978; Kosach et al., 1984). It is a perennial plant that reaches a height of 1.5 to 2.5 $\mathrm{m}$ and has several erect stems that arise from a 
rhizome structure. The first year growth is in the form of rosette with low DM yield, but in the following years, the production ranges between 15 to $21 \mathrm{t} \mathrm{DM} \mathrm{ha}^{-1}$ under a single-cut utilization regime (Pichard et al., 1988; Filatov and Rudenko, 1982; Niqueux, 1981). Slightly lower yields have been reported by Albrecht and Goldstein (1997) under a two-cut regime.

Cup-plant initiates growth during spring, after completing its vernalization requirements, and grows rapidly, attaining its maximum biomass accumulation by late summer. It has a long growing season and exhibits rapid regrowth after cutting (Solov'yanova, 1975). Various authors recommend utilization at the bud stage, which allows some regrowth over the summer months and a second cutting (Utevsh, 1976; Medvedev and Sidorova 1976; Albrecht and Goldstein, 1997). Such a two-cut regime lowers the total yield but results in better nutritive value and higher voluntary intake by animals. Under the severe summer drought conditions observed in the Chilean Mediterranean environment, this forage species has been well consumed when green chopped and offered to animals. In farming conditions, cupplant has sustained steers weight gains over 800 $\mathrm{g} \mathrm{d}^{-1}$ when comprising a large proportion of their daily intake. Although those observations lasted a short period (Pichard, unpublished), they are a positive indication of its feeding potential. The two-cut regime would permit a continuous supply of forage to animals for a period of approximately five months during the summer drought (Pichard et al., 1988). The conservation of cup-plant by ensiling was suggested by Chuiko et al. (1975); in more recent experiments, Lehmkuhler et al. (2007) state that cup-plant silage has a nutritional value lower than corn silage, but it can be successfully incorporated as one component of the diet or be allocated to animals with lower energy requirements.

This work was undertaken to evaluate the adaptation and productivity of cup-plant in the main soil series and climates found in the southern latitudes of Chile, near $40^{\circ} 50^{\prime} \mathrm{S}$ and $73^{\circ} 10^{\prime} \mathrm{W}$. The effects of plant density, cutting regime, and $\mathrm{N}$ and $\mathrm{P}$ fertilization upon the forage yield, plant components, and nutritional characteristics were studied.

\section{Materials and methods}

Three distinct locations, which represent the primary agroecological environments found in southern Chile, were chosen as the study sites for this series of experiments. The study area corresponds to a subhumid Mediterranean-type climate with winter rainfall and major oscillations in the daily temperature (Table 1). During the summer season, severe droughts occur, and despite a deep rooting capacity, the low and infrequent summer rainfall restricts moisture availability to a thin soil surface. The soil types are andisols that originated from volcanic ashes, and the $\mathrm{pH}$ ranged between 5.2 and 5.6.

\section{Soil characteristics}

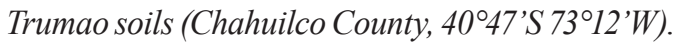
These udand soils originate from modern volcanic typic dystrandept and have a fine to intermediate texture up to a depth of $2 \mathrm{~m}$. The topography is undulating, with a 2 to $5 \%$ slope and excellent drainage. They are very fertile acidic soils, $\mathrm{pH}$ 5.6, and $18 \%$ organic matter $(\mathrm{OM})$, although the high $\mathrm{Al}$ and $\mathrm{Mn}$ concentrations are toxic to some plant species. The initial concentrations of $\mathrm{P}_{2} \mathrm{O}_{5}$ (Olsen), $\mathrm{K}_{2} 0$ and $\mathrm{S}$ were 5.0, 180.0 and 12.0 , respectively.

Nadi soils (Nochaco County, 40 ${ }^{\circ} \mathrm{S} 58^{\prime} \mathrm{W}$ ). These are hydromorphic aquands with rather flat slopes ( 0 to $1 \%$ ) that originated from modern volcanic ashes. The soil depth can reach 0.3 to $1.2 \mathrm{~m}$, with an iron and aluminum hardpan layer called "fierrillo" between the soil and subsoil that causes severe drainage problems during the winter rainy months. The organic matter content was $24 \%$, the 
Table 1. Climate characteristics for the areas in study ${ }^{1}$

\begin{tabular}{lccc}
\hline & \multicolumn{3}{c}{ Study Sites } \\
\cline { 2 - 4 } & La Unión & Chahuilco & Nochaco \\
\hline Avg. Temperature and range $\left({ }^{\circ} \mathrm{C}\right)$ & $13.9(2.8-12.4)$ & $10.7(2.0-22.0)$ & $10.0(3.1-19.7)$ \\
Avg. Temperature $\left({ }^{\circ} \mathrm{C}\right)$ in warmest month & $19.2(\mathrm{Jan})$ & $14.9(\mathrm{Jan})$ & 14.3 (Jan) \\
Avg. Temperature $\left({ }^{\circ} \mathrm{C}\right)$ in coldest month & $8.1(\mathrm{July})$ & $5.9(\mathrm{July})$ & 6.4 (July) \\
Frost free period and months number & Oct. $15(5)$ & Nov. $15(4)$ & Nov. $15(3)$ \\
Beginning vegetative growth & September & October & November \\
Average rainfall, mm yr ${ }^{-1}$ & 1277 & 1303 & 1420 \\
Maximum monthly rainfall, mm & 221 (July) & 181 (July) & 202 (July) \\
Minimum monthly rainfall, $\mathrm{mm}$ & 49 (January) & 45 (January) & 62 (February) \\
Dry period, month number & 4 & 5 & $1-2$ \\
\hline
\end{tabular}

${ }^{1}$ Source: Values recorded in situ during the three years experimental period.

${ }_{3}^{2}$ Month without temperatures under $0{ }^{\circ} \mathrm{C}$.

${ }^{3}$ Number of month when rainfall is below the requirements of half the potential evapotranspiration.

$\mathrm{pH}$ was 5.4, and the concentrations of $\mathrm{P}_{2} \mathrm{O}_{5}$ (Olsen), $\mathrm{K}_{2} 0$ and $\mathrm{S}$ were 1.0, 94.0 and 9.0, respectively. At this site, in addition to the very low phosphorus concentrations, the main limitations come from the seasonally high water table, the short growing period for plants, and the difficulties of utilizing forages in wet conditions. However, the same water table provides moisture for longer duration during the summer dry season, thus sustaining plant growth.

Red clay soils (La Unión County, 40 $17^{\circ} \mathrm{S} 73^{\circ} 05^{\prime} \mathrm{W}$ ). These andisols originate from old volcanic ash and have a very fine texture, with a soil depth that varies from 0.4 to $1.2 \mathrm{~m}$. The topography is very complex, with mild slopes ( 3 to $5 \%$ ) that alternate with steep slopes $(>20 \%)$ in hilly areas. The soils frequently exhibit moderate to severe erosion; they are acidic ( $\mathrm{pH}$ 5.2), have lower OM content (8.0\%), and suffer extreme water deficit during the summer season. The concentrations of $\mathrm{P}_{2} \mathrm{O}_{5}$ (Olsen), $\mathrm{K}_{2} 0$ and $\mathrm{S}$ were 8, 140 and 7, respectively, at the beginning of the experiments.

\section{Germplasm, experimental plots and management}

Plant germplasm was originally obtained from INRA (Clermont Ferrand, France) and examined over several years for productive behavior and sanitary purposes at the Pirque Experimental Station of the School of Agriculture. Later, the seed was harvested and used for the experiments described in this manuscript.

The plots were either directly sown or transplanted in 6 rows 4 meter long and with $0.6 \mathrm{~m}$ between rows, making $12 \mathrm{~m}^{2}$ plots. In the treatments of the plant population experiment, the plots were wider to allow equal number of rows. The seeding rate in direct sowing was $10 \mathrm{~kg} \mathrm{ha}^{-1}$, yielding an average population of 140,000 plants ha $^{-1}$. At each site, the plots were arranged in complete randomized blocks with three replicates. The soil was treated with trifluraline (48\% EC at $2 \mathrm{~L} \mathrm{ha}^{-1}$ ) prior to seedbed preparation. Except for the fertilization trials, all of the plots were fertilized with $30 \mathrm{~kg} \mathrm{~N}$ $\mathrm{ha}^{-1}, 400 \mathrm{~kg} \mathrm{P}_{2} \mathrm{O}_{5} \mathrm{ha}^{-1}$, and $100 \mathrm{~kg} \mathrm{~K}_{2} \mathrm{O} \mathrm{ha}^{-1}$ prior to sowing or planting; the high doses of phosphorus and potassium were intended to overcome their eventual deficiency. Furthermore, $100 \mathrm{~kg} \mathrm{~N} \mathrm{ha}^{-1}$ was spread in two doses during that spring and summer of the establishment year. Any additional weed control was performed manually, and no irrigation was applied. After the establishment year, $100 \mathrm{~kg} \mathrm{~K}_{2} \mathrm{O}$ ha $^{-1}$ and $200 \mathrm{~kg} \mathrm{~N}^{-1}$ were applied annually, with the nitrogen being split in three applications over the growing season. The fertilizers used were triple superphosphate ( $47 \%$ $\left.\mathrm{P}_{2} \mathrm{O}_{5}\right)$, potassium sulfate $\left(50 \% \mathrm{~K}_{2} \mathrm{O}, 18 \% \mathrm{~S}\right)$ and sodium nitrate $\left(16 \% \mathrm{~N}, 0.5 \% \mathrm{~K}_{2} \mathrm{O}, 0.1 \% \mathrm{~S}\right)$. The experiments were monitored over a three-year period, including two productive seasons. 
At harvest time, samples were obtained from four linear meters randomly chosen in the four central rows. The side rows and one meter at all row ends were discarded to avoid border effects. The plants were cut $18 \mathrm{~cm}$ above the ground, with fresh weight recorded in a field scale and, unless otherwise specified, a subsample of 8 to 10 plants with two to three stems each was saved for drying, leaf and stem separation, and chemical analyses. All of the samples were coarsely chopped, weighed and dried in a forced air oven at $60{ }^{\circ} \mathrm{C}$ to constant weight, then equilibrated to room humidity overnight and ground to pass through a 2-mm screen for laboratory analysis. Absolute dry matter, crude protein, plant cell wall fractions (NDF, ADF, and lignin) and in vitro dry matter digestibility (IVDMD) were determined according to the methods of AOAC (1990), Van Soest et al. (1991) and Goering and Van Soest (1970).

\section{Experiment 1. Plant population density}

The seedlings were prepared by direct sowing in a soil bed 45 days prior to the date foreseen for transplantation, which occurred when they had five leaves. Planting was in five plant densities by transplanting in rows set at different distances and thinning all rows to an average of 8.32 plants per linear meter, equivalent to 12-cm intervals along the row (Table 2); this was completed in September (La Unión), October (Chahuilco) and November (Nochaco). The plants were harvested at flower initiation starting on February $10^{\text {th }}$ of the second and third years, and the DM yield, plant height, stem diameter, plant components, and moisture content were determined. The yield data were compared using analysis of variance (ANOVA) using the general linear model procedure in a $2 \times 5$ factorial arrangement for year (x2), plant population (x5) and their interaction effects, independently in the three experimental sites (Table 3). The effect of plant population on morphological characteristics was studied using regression analysis (Snedecor and Cochrane, 1967) including the three replicates from each site.

\section{Experiment 2. Cutting regime}

This experiment was directly sown in autumn at a seed rate of $10 \mathrm{~kg} \mathrm{ha}^{-1}$ and later thinned to approximately 140,000 plants $\mathrm{ha}^{-1}$. Six treatments were obtained by delaying the first cut over six successive phenological stages: early vegetative, $80 \mathrm{~cm}$ height (S1); vegetative, $100 \mathrm{~cm}$ height (S2); bud stage (S3); 10\% bloom (S4); 50\% bloom (S5); and seed setting (S6). Regrowth was cut in April for all treatments. Plant height and fresh weight were measured in the field, and subsamples were saved for the separation of leaves and stems, drying and further chemical analysis. The dry matter yield of the first cut was used to calculate the mean growth rate at each site, and the cumulative yield was the sum of the first growth and the subsequent regrowth.

Table 2. Plant population density treatments.

\begin{tabular}{lccccc}
\hline $\begin{array}{l}\text { Treatments } \\
\text { Distance }\end{array}$ & D1 & D2 & D3 & D4 & D5 \\
\hline $\begin{array}{l}\text { between rows, } \\
\mathrm{cm}\end{array}$ & 80 & 70 & 60 & 50 & 40 \\
$\begin{array}{l}\text { Plant } \\
\text { population, } \\
\text { plants ha }\end{array}$ & 104,000 & 119,000 & 139,000 & 167,000 & 208,000 \\
\end{tabular}

\section{Experiments 3 and 4. Nitrogen and phosphorus fertilization}

In the $\mathrm{N}$ experiment, planting was by direct seeding at a rate of $10 \mathrm{~kg}$ of seed ha $\mathrm{h}^{-1}$ drilled in rows 60 $\mathrm{cm}$ apart and thinned to 140,000 plants $^{-1} \mathrm{~b}^{-1}$ before 60 days. The field used for the $\mathrm{N}$ experiment was fertilized with $400 \mathrm{~kg} \mathrm{P}_{2} \mathrm{O}_{5} \mathrm{ha}^{-1}$ and $100 \mathrm{~kg} \mathrm{~K}_{2} \mathrm{O}$ $\mathrm{ha}^{-1}$ during the soil preparation prior to seeding, using triplesuperphosphate and potassium sulfate. Nitrogen fertilizer was applied as sodium nitrate at rates of $0,100,200,300$, and $400 \mathrm{~kg} \mathrm{~N} \mathrm{ha}^{-1} \mathrm{yr}^{-1}$ 
in three monthly intervals, starting in August through October, depending on the onset of the growing season in each area of the study. The $\mathrm{P}$ experiment plots were established by transplanting, as in the previous experiment, to attain 140,000 plants $\cdot \mathrm{ha}^{-1}$ after fertilization with treatments of 0 , 100, 200, 300, and $400 \mathrm{~kg} \mathrm{P}_{2} \mathrm{O}_{5}$ ha $^{-1}$ using triplesuperphosphate due to its high concentration ( $47 \%$ $\mathrm{P}_{2} \mathrm{O}_{5}$ ) and availability in the form of monocalcium phosphate. $\mathrm{N}$ and $\mathrm{K}$ were applied prior to planting at rates of 30 and $100 \mathrm{~kg} \mathrm{~N}$ and $\mathrm{K}_{2} \mathrm{O} \mathrm{ha}^{-1}$ as sodium nitrate and potassium sulfate, respectively. Nitrogen was top-dressed to reach $200 \mathrm{~kg} \mathrm{~N} \mathrm{ha}^{-1}$ $\mathrm{yr}^{-1}$ in three monthly applications, starting in late winter. Annual applications of $\mathrm{P}$ were repeated every year during August, at rates of 0, 40, 80, 120 and $160 \mathrm{~kg} \mathrm{P}_{2} \mathrm{O}_{5}$ ha $^{-1}$, respectively, according with the treatments. At La Unión, the planting failed, and no results are reported for that site for the $\mathrm{P}$ experiment. In both the $\mathrm{N}$ and $\mathrm{P}$ experiments, the plants were harvested at $50 \%$ bloom, in accordance with the previous sampling technique, and the fresh weight and plant height were measured in the field. Subsamples were taken for moisture determination and for laboratory analyses.

\section{Results and discussion}

\section{Experiment 1. Effect of population density}

Dry matter yield. Annual DM yield ranged from 9.6 to $22.3 \mathrm{t} \mathrm{ha}^{-1}$ for the two harvest years (Table $3)$. There were no differences $(\mathrm{P} \geq 0.05)$ in yield associated with plant density, except for the second year in La Unión, where there was a treatment $x$ year interaction (Figure 1). At that site, in the first harvest year, the yields were low and very uniform across the plant densities, which might be attributed to the severe summer drought, indicating that soil moisture would restrict plant growth before any other factor. During the second harvest year at La Unión, the treatment with the lowest density had a lower dry matter production $(\mathrm{P} \leq 0.05)$ than the other density levels, which could be explained by a suboptimal canopy density for utilization of radiation during the growing season.

At all sites, the DM yield was lower for the lowest plant densities (Figure 1), although not statistically significant $(\mathrm{P} \geq 0.05)$, suggesting that the seeding rates need to be adjusted to produce at least 120,000 plants $\mathrm{ha}^{-1}$. The greater population densities did affect the plant morphology, but the yield components tended to compensate, and no significant effect $(\mathrm{P} \geq 0.05)$ was observed on biomass yield. The greatest yields were obtained at Chahuilco, which are likely due to better soil and climate conditions, rather than to latitude or radiation effects, as this site is located in between La Unión and Nochaco. In the region where this research was conducted, the cup-plant produced as much forage as a good alfalfa stand in its second year, in the range of 15 to $20 \mathrm{t} \mathrm{DM} \mathrm{ha}^{-1}$; similarly, red clover, either in pure stand or mixed with hybrid ryegrasses, may yield up to $15 \mathrm{t} \mathrm{DM}$ ha- 1 in the second growing season but lasts only 2 to 3 years (Teuber et al., 2008). The cup-plant has a lower

Table 3. Average dry matter yield and significance of year and population density effects.

\begin{tabular}{|c|c|c|c|c|c|c|}
\hline & \multicolumn{2}{|c|}{ Chahuilco } & \multicolumn{2}{|c|}{ La Unión } & \multicolumn{2}{|c|}{ Nochaco } \\
\hline Year 1 & 22,288 & $(2.37)^{1}$ & 9,629 & $(0.98)$ & n.a. ${ }^{2}$ & \\
\hline Year 2 & 19,388 & $(2.76)$ & 14,641 & (3.14) & 17,851 & $(2.21)$ \\
\hline \multicolumn{7}{|l|}{ Effects } \\
\hline Year & $*$ & & $* *$ & & n.a. & \\
\hline Plant population & NS & & $*$ & & NS & \\
\hline Year x plant pop. & NS & & ** & & n.a. & \\
\hline
\end{tabular}

${ }^{1}$ Italic numbers between brackets represent standard deviations of the mean.

${ }^{2}$ n.a. $=$ not available.

$* \mathrm{P} \leq 0.05 ; * * \mathrm{P} \leq 0.01$ 


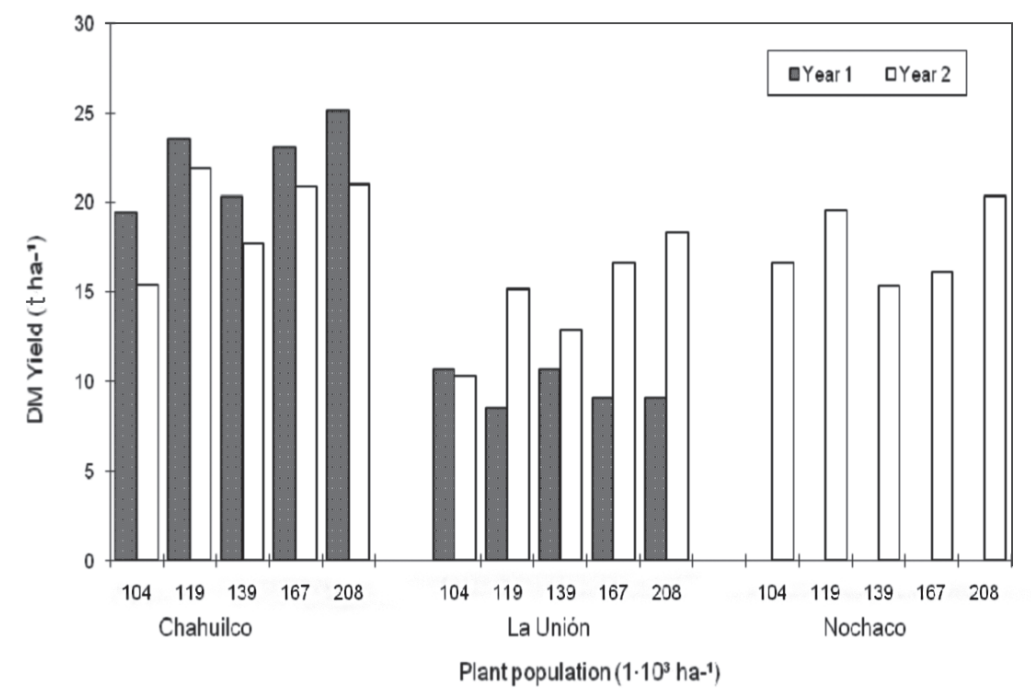

Figure 1. Effect of plant population on dry matter yield of Silphium perfoliatum.

nutritional value than the mentioned legumes and relies on nitrogen fertilization, but it is very well adapted, truly perennial, not subjected to winter injury, and does not require heavy liming as alfalfa does in acidic soils. It can be considered a good yielding and reliable species.

Plant height, stems per plant, stem diameter and proportion of leaves. Population density is known to increase competition between adjacent plants, to modify shading and to stimulate stem elongation (Hay and Porter, 2006). In this study, an inverse linear relationship was observed between plant height and plant density at Chahuilco and at Nochaco. We observed a morphological compensation in cup-plant, a reduction in the number of stems per plant in response to the higher plant population density at all three sites (Table 4). Similarly, the stem diameter decreased linearly as population density increased, and this effect was the most dramatic in Nochaco, where a doubling of the population density reduced the stem width by half. Similar morphological responses to high population densities have been observed in stem diameter in sunflower (Helianthus annus) and in maize (Zea mays) by Escalante-Estrada et al. (2008) and earlier by Matus (1985) and Trivelli (1984). In Nochaco, where the plants grew less tall, the increases in population densities led to decreases in height. These results could suggest that competition for soil nutrients was more important than light limitation with increasing plant density, although the amounts of N, $\mathrm{P}$ and $\mathrm{K}$ applied were thought to be adequate for all treatments. However, the shorter plants at Nochaco did not have proportionally low yields (Figure 1); instead, they developed a high number of stems per plant, thicker stems and a higher percentage of leaves, suggesting a hormonal adaptation to the lower radiation and lower temperatures that characterize this site. The contribution of leaves to the DM yield varied from $33 \%$ to $45 \%$ and was higher $(\mathrm{P} \leq 0.05)$ at the lower population densities. This was due mainly to poor leaf retention in the shaded environment produced by the dense canopies. Harvesting at an earlier growth stage may result in higher leaf:stem ratios, with the consequent improvement in nutritional quality.

Across all population densities at Chahuilco, the site with no soil limitations and the longest growing season, the yields were greater and plants were taller than in the other sites. The more vigorous growth observed was accompanied by greater shading effects and lower leaf percentages, and this effect was more pronounced at the higher population densities (Table 4). The number of stems per plant was greatest at Chahuilco and Nochaco, 
which were also the sites where the highest DM yields were recorded, suggesting that the number of stems is a major component of the total yield. It was observed that the tallest and highest yielding plants fairly rapidly lost their lower and middle stem leaves, keeping only those on the top 50 or $70 \mathrm{~cm}$ of the plant. This explains why the thicker stems, which were presumably heavier, that were found at the lowest population densities were not accompanied by lower leaf:stem ratios. In fact, across the three sites, the proportion of leaves declined as the plant density increased.

\section{Experiment 2. Cutting regime}

When cutting at the early vegetative stage, plants were approximately $80 \mathrm{~cm}$ tall and yield was close to $5 \mathrm{t} \mathrm{DM} \mathrm{ha}^{-1}$ at all three sites (Figure 2), whereas delaying the initial harvest until seed formation resulted in yields between 15.7 to $20.6 \mathrm{t} \mathrm{DM} \mathrm{ha}{ }^{-1}$. A linear relationship was observed for the net yield of the first cut with mean growth rates of $168 \mathrm{~kg}$ DM ha ${ }^{-1} \mathrm{~d}^{-1}$ in Chahuilco, $133 \mathrm{~kg} \mathrm{DM} \mathrm{ha}^{-1} \mathrm{~d}^{-1}$ in La Unión, and $136 \mathrm{~kg} \mathrm{DM} \mathrm{ha}^{-1} \mathrm{~d}^{-1}$ in Nochaco. Cupplant is a plant that rapidly generates new shoots

Table 4. Effect of plant population on morphological characteristics of Silphium perfoliatum.

\begin{tabular}{|c|c|c|c|c|c|}
\hline \multirow{3}{*}{$\begin{array}{l}\text { Plant } \\
\text { population }\end{array}$} & \multirow{3}{*}{$\begin{array}{l}\text { Plant } \\
\text { Height } \\
\mathrm{cm}\end{array}$} & \multirow[b]{3}{*}{ Stems/plant } & \multicolumn{2}{|c|}{ Stem diameter } & \multirow{3}{*}{$\begin{array}{c}\text { Leaves } \\
\%\end{array}$} \\
\hline & & & Base & Middle & \\
\hline & & & \multicolumn{2}{|c|}{$\mathrm{cm}$} & \\
\hline \multicolumn{6}{|l|}{ Chahuilco } \\
\hline D1 & 265 & 3.2 & 1.4 & 1.13 & 36 \\
\hline D2 & 262 & 3.7 & 1.2 & 0.94 & 34 \\
\hline D3 & 256 & 2.9 & 1.2 & 0.92 & 34 \\
\hline D4 & 254 & 2.8 & 1.2 & 0.92 & 36 \\
\hline D5 & 252 & 2.3 & 1.1 & 0.83 & 33 \\
\hline $\mathrm{b}$ & -0.12 & -0.01 & -0.002 & -0.002 & -0.01 \\
\hline$r^{2}$ & 0.86 & 0.78 & 0.54 & 0.69 & 0.11 \\
\hline Sy.x & 2.36 & 0.28 & 0.09 & 0.07 & 1.38 \\
\hline
\end{tabular}

$\begin{array}{cccccc}\text { La Unión } & & & & & \\ \text { D1 } & 176 & 2.3 & 1.3 & 0.97 & 45 \\ \text { D2 } & 181 & 2.4 & 1.1 & 0.92 & 40 \\ \text { D3 } & 182 & 1.8 & 1.1 & 0.91 & 42 \\ \text { D4 } & 166 & 2.1 & 1.1 & 0.82 & 44 \\ \text { D5 } & 200 & 2.0 & 1.0 & 0.78 & 37 \\ \text { b } & 0.15 & -0.003 & -0.002 & -0.002 & -0.048 \\ \text { r }^{2} & 0.26 & 0.23 & 0.76 & 0.95 & 0.38 \\ \text { Sy.x } & 12.21 & 0.21 & 0.05 & 0.02 & 2.89\end{array}$

\begin{tabular}{cccccc} 
Nochaco & & & & \\
D1 & 187 & 3.0 & 2.2 & 1.7 & 44 \\
D2 & 188 & 3.4 & 2 & 1.5 & 41 \\
D3 & 178 & 2.5 & 1.6 & 1.1 & 34 \\
D4 & 168 & 2.6 & 1.3 & 0.9 & 36 \\
D5 & 159 & 2.6 & 1 & 0.7 & 36 \\
b & -0.296 & -0.006 & 0.012 & -0.010 & -0.069 \\
r & 0.96 & 0.39 & 0.95 & 0.91 & 0.47 \\
Sy.x & 2.72 & 0.34 & 0.12 & 0.14 & 3.47 \\
\hline${ }^{1} \mathrm{D} 1=104,000 ; \mathrm{D} 2=119,000 ; \mathrm{D} 3=$ & 139,$000 ; \mathrm{D} 4=167,000 ; \mathrm{D} 5=208,000$ plants $^{2} \cdot \mathrm{ha}^{-1}$.
\end{tabular}


from the crown once the older ones have been cut. Thus, depending on the time of the initial harvest, a second harvest can be completed during the growing season. In Figure 2, it can be observed that the later the date of the first cut, the higher the overall yield but the lower the contribution of the regrowth. This effect was greater at the sites with shorter growing seasons, as the secondary growth following the initial harvest was under less favorable conditions until the final harvest in April.

Plant height and the proportion of leaves and stems were influenced by the cutting regime. The differences in plant height mirrored the yield differences (Figure 3). In the initial growth, the proportion of leaves decreased sharply from over $60 \%$ in the early vegetative stage to close to $40 \%$ at the onset of the reproductive stage (Figure 4). The secondary growth when the first cut was at early stages of plant development was approximately $60 \%$ leaves, whereas regrowth of those submitted to the first cut at later stages ( $\mathrm{S} 3$ to S6) were essentially pure leaves. This advantage would be cancelled by the very low yield of the secondary growth after the late first cut.

The average dry matter content of the cup-plant increased from $144 \mathrm{~g} \cdot \mathrm{kg}^{-1}$ in the early vegetative

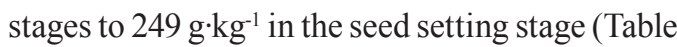
5). At Chahuilco, after the onset of flowers, the plants had greater dry matter content than at the other two sites at equivalent phenological stages; this may be due to the faster growth rate observed at this site. The moisture content of the plant was very much influenced by the leaf:stem ratio, as leaves have lower water content than stems in early stages, and in later stages, stems become richer in dry matter content than leaves (Table 6). The senescence of the shaded leaves and the progressive maturation of the stem tissues would be involved in this observation. At Nochaco and La Unión, the same phenological stages were attained later in the growing season, but at Nochaco, the plants were richer in dry matter than at La Unión (Table 5), which is consistent with the observed higher proportion of leaves (Table 4).

The crude protein content and IVDMD rapidly declined as the plants progressed from the vegetative stages to the reproductive ones. In the early vegetative stages, $\mathrm{CP}$ ranged between 130 and $150 \mathrm{~g} \cdot \mathrm{kg}^{-1}$, whereas by the bud stage, it had declined to $100 \mathrm{~g} \mathrm{~kg}^{-1}$, and at seed setting, the $\mathrm{CP}$ dropped to a range of 50 to $80 \mathrm{~g} \cdot \mathrm{kg}^{-1}$. This is mainly due to the very low $\mathrm{N}$ level of the stems and to the lower proportion of leaves in the more advanced stages of development. These protein values are lower than reported by Albrecht and Goldstein (1997) but similar to those found by Lehmkuhler et al. (2007). In our experiments, such value was probably influenced by the $\mathrm{N}$ fertilization rate that was used, as we observed in the next experiments, at fertilization levels greater than $200 \mathrm{~kg} \mathrm{~N} \cdot \mathrm{ha}^{-1}$, there was a response in yield and also in the protein content of the plant. The protein content of cup-plant species in vegetative stages are similar to most nonleguminous herbaceous species and compare well with other members of the Heliantheae tribe (Schingoethe et al., 1980); however, as cup-plant

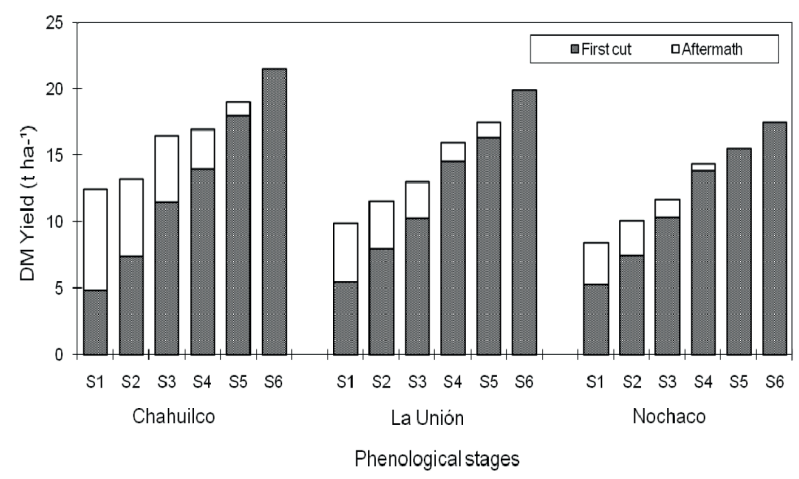

Figure 2. Effect of phenological stage of Silphium perfoliatum on first cut and aftermath forage yields. 


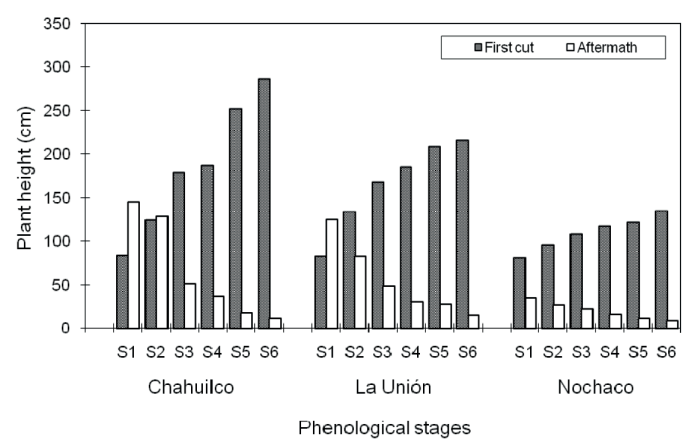

Figure 3. Effect of phenological stage on plant height of Silphium perfoliatum in first growth and in aftermath.

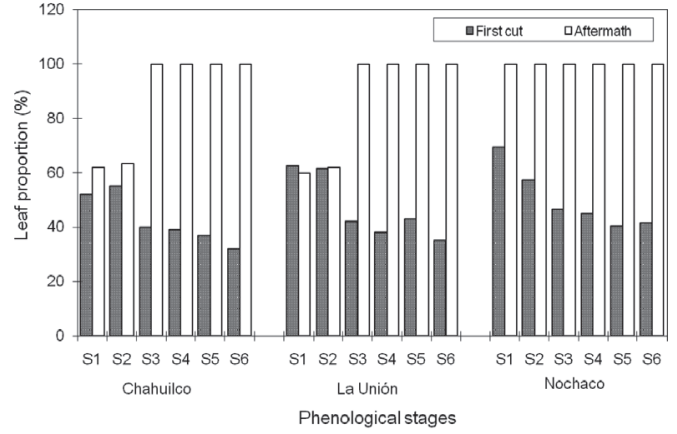

Figure 4. Effect of phenological stage of Silphium perfoliatum on leaf proportion in first growth and in aftermath.

Table 5. Effect of the phenological stages on the chemical composition and digestibility $\left(\mathrm{g} \mathrm{kg}^{-1}\right)$ of first cut Cup-plant.

\begin{tabular}{|c|c|c|c|c|}
\hline & Chahuilco & La Unión & Nochaco & Average \\
\hline \multicolumn{5}{|c|}{ Dry matter } \\
\hline $\mathrm{S} 1^{1}$ & 154 & 119 & 160 & 144 \\
\hline S2 & 173 & 123 & 208 & 168 \\
\hline S3 & 215 & 137 & 212 & 188 \\
\hline S4 & 239 & 172 & 219 & 210 \\
\hline S5 & 260 & 202 & 239 & 234 \\
\hline S6 & 266 & 234 & 247 & 249 \\
\hline \multicolumn{5}{|c|}{ Crude protein } \\
\hline $\mathrm{S} 1$ & 135 & 151 & 134 & 140 \\
\hline S2 & 99 & 118 & 126 & 114 \\
\hline S3 & 79 & 92 & 97 & 89 \\
\hline S4 & 68 & 74 & 83 & 75 \\
\hline S5 & 73 & 64 & 77 & 71 \\
\hline S6 & 57 & 51 & 78 & 62 \\
\hline \multicolumn{5}{|l|}{ NDF } \\
\hline $\mathrm{S} 1$ & 198 & n.a. ${ }^{2}$ & 189 & 194 \\
\hline S2 & 245 & 372 & 247 & 288 \\
\hline S3 & 353 & 427 & 315 & 365 \\
\hline S4 & 324 & 470 & 294 & 363 \\
\hline S5 & 297 & 477 & 335 & 370 \\
\hline S6 & 340 & 403 & 376 & 373 \\
\hline \multicolumn{5}{|l|}{ IVDMD } \\
\hline $\mathrm{S} 1$ & 805 & 784 & 779 & 789 \\
\hline S2 & 714 & 752 & 778 & 748 \\
\hline S3 & 669 & 684 & 728 & 694 \\
\hline S4 & 655 & 643 & 667 & 655 \\
\hline S5 & 640 & 582 & 637 & 622 \\
\hline S6 & 613 & 530 & 608 & 584 \\
\hline
\end{tabular}

${ }^{1} \mathrm{~S} 1=$ vegetative $80 \mathrm{~cm}$ height, $\mathrm{S} 2=$ vegetative $100 \mathrm{~cm}$ height, $\mathrm{S} 3=$ bud stage, $\mathrm{S} 4=$ $10 \%$ flower, $\mathrm{S} 5=50 \%$ flour, S6 $=$ seed stage.

${ }^{2}$ n.a. = not available. 
approached the reproductive phases, the protein content dropped very sharply.

The plant cell wall content of the early vegetative stages was very low, which is interesting given that the $5 \mathrm{t} \mathrm{ha}^{-1}$ forage DM already accumulated and also explains the high digestibility values observed in that stage. At La Unión, the plant cell wall content of cup-plant was consistently higher than at the other two sites; this should be a joint effect of higher environmental temperature (Table 1) and the consequent moisture stress on cell wall synthesis, as explained by Deinum and Dirven (1976) and by Minson (1990). This higher cell wall content at La Unión had a major negative impact on digestibility for the two most mature stages; the drop in IVDMD from the early vegetative to seed stage was $254 \mathrm{~g} \mathrm{~kg}^{-1}$. At Nochaco, there was a greater leaf:stem ratio, and the IVDMD total reduction was only $171 \mathrm{~g} \cdot \mathrm{kg}^{-1}$. The digestibility values prior to the bud stage were very high at all three sites. From a nutritional standpoint, this species has low plant cell wall content and compares favorably with the leafy forages of the Brassica genus and with alfalfa (Han et al., 2000).

The changes in the chemical composition of the leaves and stems during plant development were studied more in depth at Chahuilco (Table 6). During the vegetative stages (S1 and S2), the DM contents of the leaves and stems were close to 140 and $100 \mathrm{~g} \cdot \mathrm{kg}^{-1}$, respectively. This finding indicates that the plants were very succulent during the periods of highest nutritive value, making them very palatable for grazing animals or for green chopped direct feeding but too wet and probably unsuitable for conservation as silage. Once the reproductive stages had begun, the DM content increased to approximately $200 \mathrm{~g} \cdot \mathrm{kg}^{-1}$ and was similar in leaves and stems. The ash content of the leaves remained approximately $140 \mathrm{~g} \cdot \mathrm{kg}^{-1}$ throughout the study period and was high relative to many domestic grasses and legumes (MAFF, 1992); the ash content of the stems was lower and declined by approximately one-half as the plant grew older.
In the progressive growth stages, the protein content in the leaves and stems dropped quite sharply from 200 and 52 to 108 and $15 \mathrm{~g} \mathrm{~kg}^{-1}$, respectively. The proportion of soluble $\mathrm{N}$ in both the leaves and stems was in the low range for most forages (Pichard and Van Soest, 1977), particularly during the early stages of development, which suggests that cup-plant will probably never have any nitrate toxicity problems nor accumulate high levels of NPN compounds. The amount of fiber bound nitrogen (acid detergent insoluble nitrogen, ADIN) was also very low in the leaves and apparently high in the stems, but the latter is an artifact of the calculations because the $\mathrm{N}$ content of the stems is very low.

The composition of the cell walls in the leaves and stems of cup-plant show that lignocellulose is the main component, and hemicellulose is much less important. Lignin was found in a high proportion, between 200 and $300 \mathrm{~g} \mathrm{~kg}^{-1}$ of the total plant fiber in the leaves and approximately $150 \mathrm{~g} \mathrm{~kg}^{-1}$ in the stems. The cell wall content of the leaves decreased from 300 to $240 \mathrm{~g} \mathrm{~kg}^{-1}$ from the early vegetative stage to the bud stage and then remained at the same level through the successive stages of development. This occurred because, as the growing season progressed but prior to flowering, the older leaves senesced more rapidly than the new leaves emerged such that at later sampling periods during the growing season, proportionally more new leaf tissue was present, which was slightly less fibrous and less lignified. In stages S5 and S6, no new leaves were formed, and those that remain had been submitted to high summer temperatures and were likely beginning to undergo senescence. As a result, the fiber became more complex and less available to rumen microbes, which was observed as reduced plant cell wall digestibility. The IVDMD of leaves was very high, never falling below 820 $\mathrm{g} \cdot \mathrm{kg}^{-1}$, and it was beyond what is expected from the high percentage of lignin found in leaf cell walls. In contrast, the fiber content of the stems was high from the beginning and increased from stage $\mathrm{S} 1$ to $\mathrm{S} 3$ and then leveled off approximately $600 \mathrm{~g} \mathrm{~kg}^{-1}$. The stem IVDMD started at $670 \mathrm{~g} \mathrm{~kg}^{-1}$ 
Table 6. Effect of phenological stage on the chemical composition and digestibility of leaves and stems of Cup-plant at Chahuilco.

\begin{tabular}{|c|c|c|c|c|c|c|c|c|c|c|c|c|}
\hline \multirow[b]{2}{*}{ Stages $^{1}$} & \multicolumn{6}{|c|}{ Leaves } & \multicolumn{6}{|c|}{ Stems } \\
\hline & $\mathrm{S} 1$ & S2 & $\mathrm{S} 3$ & S4 & S5 & S6 & S1 & S2 & S3 & S4 & S5 & S6 \\
\hline Dry matter, $\mathrm{g} \mathrm{DM} \mathrm{kg}^{-1}$ & 139 & 136 & 146 & 182 & 197 & 221 & 93 & 108 & 130 & 169 & 210 & 239 \\
\hline Ash, $\mathrm{g} \mathrm{DM} \mathrm{kg}^{-1}$ & 148 & 145 & 145 & 138 & 157 & 150 & 95 & 80 & 71 & 52 & 50 & 42 \\
\hline Crude protein, $\mathrm{g} \mathrm{DM} \mathrm{kg}^{-1}$ & 200 & 162 & 151 & 127 & 127 & 108 & 52 & 43 & 34 & 25 & 26 & 15 \\
\hline Soluble $\mathrm{N}, \mathrm{g} \mathrm{kg}$ total $\mathrm{N}^{-1}$ & 134 & 104 & 141 & 168 & 281 & 291 & 179 & 261 & 241 & 175 & 293 & 167 \\
\hline ADIN, $g$ kg total $\mathrm{N}^{-1}$ & 26 & 24 & 19 & 19 & 20 & 17 & 63 & 77 & 74 & 80 & 85 & 113 \\
\hline $\mathrm{NDF}, \mathrm{g} \mathrm{DM} \mathrm{kg}^{-1}$ & 300 & 264 & 246 & 242 & 244 & 234 & 525 & 557 & 604 & 589 & 612 & 600 \\
\hline $\mathrm{ADF}, \mathrm{g} \mathrm{DM} \mathrm{kg}^{-1}$ & 247 & 252 & 232 & 220 & 237 & 217 & 468 & 486 & 515 & 506 & 523 & 525 \\
\hline Lignin, g DM kg-1 & 68 & 82 & 42 & 55 & 49 & 48 & 85 & 86 & 88 & 85 & 106 & 93 \\
\hline CW Digestibility, g DM kg-1 & 891 & 904 & 885 & 922 & 825 & 783 & 619 & 514 & 456 & 370 & 300 & 227 \\
\hline DM Digestibility, g DM kg-1 & 838 & 839 & 843 & 852 & 828 & 820 & 671 & 600 & 543 & 500 & 443 & 407 \\
\hline
\end{tabular}

${ }^{1} \mathrm{~S} 1=$ vegetative $80 \mathrm{~cm}$ height, $\mathrm{S} 2=$ vegetative $100 \mathrm{~cm}$ height, $\mathrm{S} 3=$ bud stage, $\mathrm{S} 4=10 \%$ flower, $\mathrm{S} 5=50 \%$ flour, $\mathrm{S} 6=$ seed stage $\mathrm{ADIN}$ : acid detergent insoluble nitrogen.

NDF: neutral detergent fiber.

ADF: acid detergent fiber.

CW: cell wall.

in the early vegetative stage but declined sharply and steadily over the entire study period to $400 \mathrm{~g}$ $\mathrm{kg}^{-1}$; the stem IVDMD was primarily influenced by the complexity of the fiber matrix rather than by the lignin content, which increased only in the final S5 and S6 stages. This limited availability of stems, in addition to the increased proportion found in more mature plants, is responsible for the overall reduction in the digestibility of cupplant as the plants progress from vegetative to late reproductive stages.

\section{Experiment 3. Nitrogen fertilization}

DM yield and plant morphology. A quadratic response to nitrogen was observed in the yield of adult plants after the establishment year (Table 7). Such decreasing efficiency with increasing nitrogen doses fits with the general knowledge about plant growth limits under varying genetic and environmental conditions (Hodgson, 1990). The maximum yield was attained at $300 \mathrm{~kg} \mathrm{~N} \mathrm{ha}^{-1}$, although at $200 \mathrm{~kg} \mathrm{~N}$ $\mathrm{ha}^{-1}$, a clear asymptote was already observed (Table 7); above $300 \mathrm{~kg} \mathrm{~N} \mathrm{ha}^{-1}$, there was a slight positive response at Chahuilco and a small yield reduction at the other two sites. This reduction has previously been interpreted as a toxicity effect on the plant, but the low rate of $\mathrm{N}$ uptake suggests that cup-plant absorbs limited quantities of $\mathrm{N}$, thus making the toxic effect reported in other forage species under heavy $\mathrm{N}$ dosing unlikely (Hopkins, 2000). The yield response curve indicates that the nitrogen supply was not a limiting factor for attaining greater forage yields when harvested in a single cut at mid-bloom stage; this maximum was approximately $20 \mathrm{t} \mathrm{DM}$ $\mathrm{ha}^{-1}$. The impact of $\mathrm{N}$ doses on yield (Table 7) was very positive for the first $100 \mathrm{~kg} \mathrm{~N}$ applied, being $51.6,45.2$ and $22.4 \mathrm{~kg} \mathrm{DM} \mathrm{kg} \mathrm{N}^{-1}$; however, further additions of the fertilizer had much lower responses, and beyond $200 \mathrm{~kg} \mathrm{~N} \mathrm{ha}^{-1}$, the effect on yield was poor. The rate of marginal recovery of the applied nitrogen was consistent with the yield responses. Recovery was remarkably low when fertilizing with more than $100 \mathrm{~kg} \mathrm{~N} \mathrm{ha}^{-1}$; at two sites, the marginal recovery of nitrogen was in the range of 5 to $10 \%$.

The plants in the control treatments without $\mathrm{N}$ fertilization were consistently shorter, and as shown in the linear regression analysis, plant height increased by 5 to $8 \mathrm{~cm}$ for every $100 \mathrm{~kg} \mathrm{~N}$ $\mathrm{ha}^{-1}$. This morphological change is well correlated 
with the yield, suggesting that plant height is a definite yield component in cup-plant when submitted to variable levels of nitrogen supply. As the plants became taller, we expected to observe a reduction in the proportion of leaves, but no such effect was found. Leaf percentage was a variable trait within each location at the different $\mathrm{N}$ fertilization rates, although at two locations the highest leaf proportion was found in the lowest $\mathrm{N}$ treatment. This finding is in contrast to the previous results observed in cool season grass species and in $\mathrm{C}_{4}$ summer crops, which show a faster senescence of lower leaves with a low $\mathrm{N}$ supply. It is likely that the better access to light by leaves of shorter and weaker plants was more important than $\mathrm{N}$ supply in determining their persistence.

Crude protein level. As shown in Tables 5 and 6, the protein content of cup-plant is not high, even at early vegetative stages, and it drops sharply once the reproductive phase begins. Similar low protein levels have been reported by Seiler (1984) for sunflower forage and by Hay and Offer (1992) for the tops of Jerusalem artichoke (H. tuberosus). In this study, cup-plant plants responded to increasing amounts of $\mathrm{N}$ application by increasing the $\mathrm{N}$ content of the plant tissue (Figure 5); however, the absolute value is still very low compared with other known forage crops. The protein content attained in the highest $\mathrm{N}$ treatment was only 6.7 , 8.2 and $6,2 \%$ in the three locations; at fertilization rates up to $200 \mathrm{~kg} \mathrm{~N} \mathrm{ha}^{-1}$, the protein content was below $6 \%$. The actual uptake of $\mathrm{N}$ varied at each site, but the concentration of $\mathrm{N}$ in the plant leveled off at the same rate of fertilization at which the same effect was observed in the biomass yield. From a nutritional perspective, such low protein content brings a clear limitation to potential uses of this forage species. This limited absorption of nitrogen is distinctly different from grass species, which can accumulate over $5 \% \mathrm{~N}$ at high rates of fertilization (Wilkins et al., 2000). Such a low requirement for $\mathrm{N}$ is however an interesting observation from an environmental viewpoint in livestock systems.
When partitioning the protein in the leaves and stems of cup-plant, the leaves contain 4 times more protein than stems in early stages, and in later stages, up to seven times more (Table 6). When fertilizing with $\mathrm{N}$, the protein content of the stems increased very slightly (Table 5), remaining at all doses below 3\%, except at $\mathrm{La}$ Unión where it reached $4.5 \%$. The crude protein content in the leaves of the control treatments was close to $11 \%$, and at the high $\mathrm{N}$ supply, it increased up to $15-17 \%$ at the different locations. This means that leaves are very important in determining the protein value of cup-plant and that field management should address as a high priority the strategies for keeping a high leaf:stem ratio in the harvested forage.

\section{Experiment 4. Phosphorus fertilization}

Plant and soil responses to $\mathrm{P}$ fertilization were not consistent across locations. At Chahuilco, there was a steady augmentation in soil $\mathrm{P}$ concentration, going from 5 to 35 ppm $\mathrm{P}_{2} \mathrm{O}_{5}$ (Figure 6); however, forage yield was high and essentially constant across all phosphorus levels. At Nochaco, a distinct response was observed. The soil phosphorus was initially very low, 1 ppm P-Olsen, and at the dose of $300 \mathrm{~kg} \mathrm{P}_{2} \mathrm{O}_{5}$ $\mathrm{ha}^{-1}$, it attained a maximum of $10 \mathrm{ppm}$ P-Olsen; the forage yield constantly increased from 0 to $400 \mathrm{~kg} \mathrm{P}_{2} \mathrm{O}_{5} \mathrm{ha}^{-1}$. Other than the initially different phosphorus content in the two soils, it was observed that when attaining comparable levels of P-Olsen, the yield was much lower at Nochaco than at Chahuilco. It is likely that the amount of exchangeable $\mathrm{Al}$ at the two sites could have caused this different response to P. At Nochaco, the $\mathrm{Al}$ concentration was $0.81 \mathrm{mg} \mathrm{kg}^{-1}$, compared with only $0.42 \mathrm{mg} \mathrm{kg}^{-1}$ at Chahuilco. The effectiveness of $\mathrm{P}$ fertilization is inversely related to the availability of free $\mathrm{Al}$ in the soil (Philippi et al., 1985). Other than climatic differences, there may be other nutrient deficiencies at Nochaco, and future research should address the role of calcium, magnesium, sulfur and microminer- 
Table 7. Effect of nitrogen fertilization on dry matter yield, plant height, leaf/stem ratio, forage yield, nitrogen uptake, and recovery.

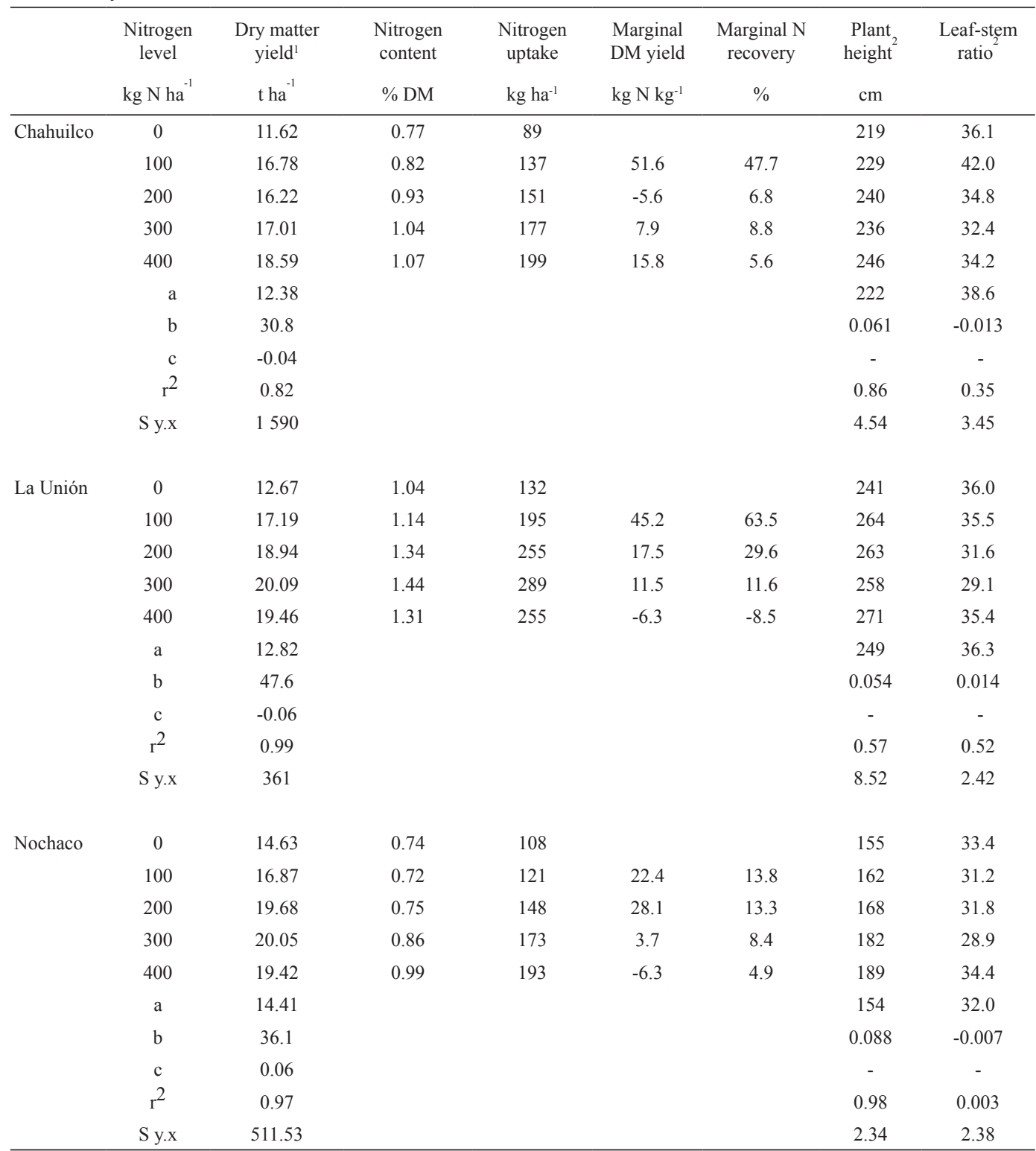

${ }^{1}$ Regression coeficients for the model $y=a+b x-c x^{2}$.

${ }^{2}$ Regression coeficients for the model $y=a+b x$.

als. The most interesting finding was the lack of yield response to phosphorus at Chahuilco, suggesting that this nutrient might not be critical for cup-plant to achieve good yields. Where plants responded to $\mathrm{P}$ fertilization, there was a positive relationship between plant height and DM yield, but $\mathrm{P}$ fertilization had no effect on the yield components.
From this study, we conclude that cup-plant can be a useful forage resource for those locations where the growth of permanent pastures is limited, especially those sites that experience severe summer drought, locations with a short growing season between the late spring and early autumn frosts, and in those locations that have hydromorphic soils saturated with water during a long winter 


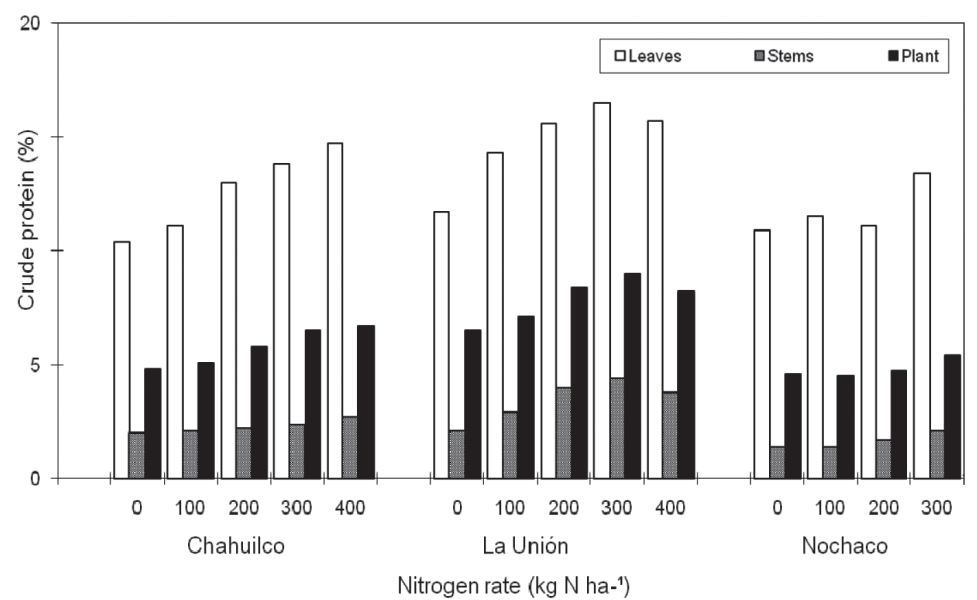

Figure 5. Effect of nitrogen fertilization on the content and distribution of protein in plants of Silphium perfoliatum.

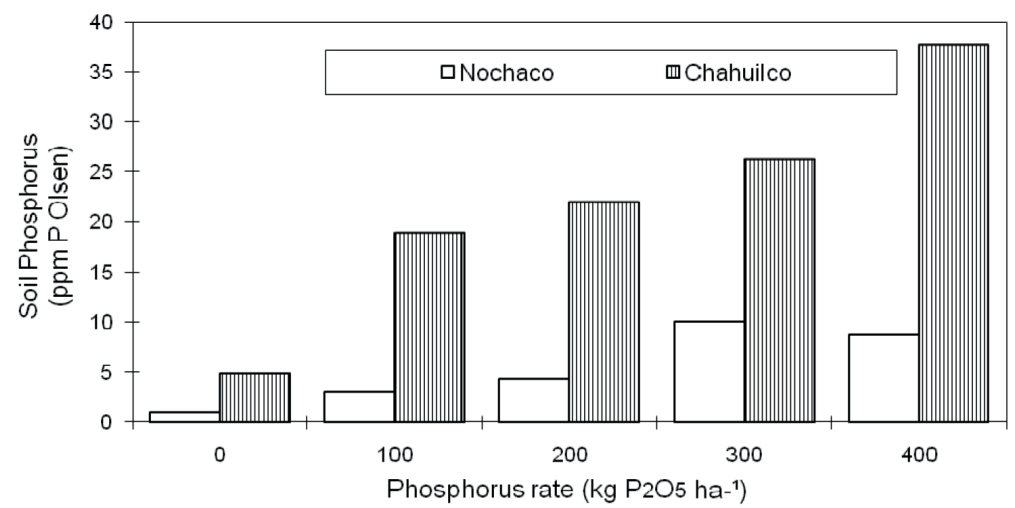

Figure 6. Effect of phosphorus fertilization on soil content of P Olsen.

period. Fast growth rates were recorded during late spring and summer, making efficient use of the inter-frost period and providing an abundant feed resource for animal needs. Cup-plant exhibits considerable morphological plasticity and adapts well to varying cropping conditions without major changes in biomass yield. Under differing population densities, the number and thickness of the stems was found to vary, but there were only minor effects on plant height and leaf:stem ratio. The data regarding nitrogen utilization support the evidence that cup-plant is a low protein species that does not absorb large quantities of nitrogen even if there is a high concentration in soil or if growing conditions favor good plant growth. Under low yielding conditions, which might induce the accumulation of nitrogen in plant tissues, cup-plant does not absorb unnecessary quantities. Protein is predominantly located in the leaves, which account for approximately one-third of plant weight in the first cut and higher percentages in the secondary growth. Even so, leaves also have low protein content, and stems have extremely low protein content. Regarding the phosphorus requirements of cup-plant, at one location, there was no yield response in low $P$ soils, suggesting that this nutrient might not be critical for the species.

The proper management of cup-plant will be critical for providing forage with an acceptable 
nutritive value. The results of these studies suggest that a first cut be completed when the plants are still vegetative to ensure that protein and available energy levels are sufficient to promote desired liveweight gains or milk production. Starting the cuts at an early vegetative stage also allows second cuts to be completed in January, thus insuring a continuous supply of forage during December through March. Such a two-cut regime reduces the overall yield compared with a single cut at the end of the season, but delaying the first cut results in a stemmy forage with very low protein and energy values. Further work is needed to assess the animal response to feeding this forage under animal production systems of varying intensities. These results suggest that the perennial and rustic characteristics of cup-plant might be particularly interesting for low input farming systems.

\section{Acknowledgment}

The authors gratefully acknowledge the assistance of Dr. Luis Barrales and Mr. Ivan Peña for statistical advice.

\section{Resumen}

G. Pichard. 2012. Manejo, producción, y características nutricionales del silfo (Silphium perfoliatum) en climas templados del sur de Chile. Cien. Inv. Agr. 39(1): 61-77. La información publicada sobre la respuesta del silfo (Silphium perfoliatum L.) a prácticas culturales es limitada. Es una planta forrajera perenne introducida en Chile en los años 70, la cual fue sometida a una serie de estudios para evaluar su adaptación y productividad. Se midió los efectos de población de plantas (104.000 - 208.000 plantas ha $^{-1}$ ), estado de desarrollo al corte (vegetativo temprano a formación de semilla) y niveles de fertilización nitrogenada $\left(0-400 \mathrm{~kg} \mathrm{~N} \mathrm{ha}^{-1}\right)$ y fosforada $\left(0-400 \mathrm{~kg} \mathrm{P}_{2} \mathrm{O}_{5}\right.$ $\left.\mathrm{ha}^{-1}\right)$. Los experimentos de campo fueron realizados durante tres años en la zona subhúmeda ( $40^{\circ} \mathrm{S}$ $73^{\circ} \mathrm{W}$ ), con clima mediterráneo, en tres tipos de andisoles originados de cenizas volcánicas, con pH 5,2 a 5,6. Se midió el rendimiento de forraje, los componentes de la planta (número de tallos, diámetro de tallo, altura de planta, relación hoja:tallo) y sus características nutricionales (proteína cruda, fibra y sus componentes, y digestibilidad in vitro). Durante el primer año las plantas tuvieron un crecimiento en roseta por lo cual las mediciones se iniciaron en la segunda primavera después de la plantación y se repitieron durante dos temporadas de crecimiento. Poblaciones de plantas superiores a 120.000 plantas ha ${ }^{-1}$ no afectaron el rendimiento de materia seca que se mantuvo entre 15 y $20 \mathrm{t} \mathrm{ha}^{-1}$. El número y diámetro de los tallos varió por efecto de la población de plantas, pero la altura y la relación hoja:tallo no fueron afectados. La proporción de hojas osciló entre 30 y $45 \%$ en los diferentes ensayos. En los experimentos sobre régimen de corte se observó que aquellos más tempranos tuvieron menores rendimientos, pero mejores características nutricionales. Cuando el primer corte se pospuso desde el estado vegetativo temprano hasta semilla formada, la proteína se redujo de 140 a $60 \mathrm{~g} \mathrm{~kg}^{-1}$ y la digestibilidad de 790 a $580 \mathrm{~g} \mathrm{~kg}^{-1}$, principalmente debido al bajo valor nutricional de los tallos. La producción y el contenido de proteína aumentaron al incrementar los niveles de fertilización de $\mathrm{N}$ y de $\mathrm{P}$. Se observó que el silfo es una especie con bajos requerimientos de nitrógeno, pero es eficiente en la producción de biomasa; la consecuencia es que genera un forraje bajo en proteína. Los resultados indican que el silfo puede ser incorporado como un cultivo forrajero perenne de crecimiento estival, siendo un complemento alimenticio de valor para los períodos de sequía en aquellas áreas donde el crecimiento de la pradera es muy afectado por la falta de humedad. Su adaptación y características productivas la hacen muy adecuada para sistemas de producción agrícola de baja intensidad.

Palabras clave: Calidad nutricional, cultivo perenne, densidad de población, fertilización, frecuencia de corte, silfo. 


\section{References}

Albrecht, K., and W. Goldstein. 1997. Silphium perfoliatum: a north american prairie plant with potential as a forage crop. In: Proc. XVIII International Grassland Congress, June 1997, Winnipeg and Saskatoon. Alberta, Canada.

AOAC, 1990. Official methods of analysis. Association of Official Analytical Chemists (AOAC). $15^{\text {th }}$ ed. Washington, D.C.

Chuiko, V.K., I.I. Pestov, and A.Y. Ivashchenko. 1975. Reserves for silage production in Poltava region. Herb. Abstr. 45(11) 4.528.

Deinum, B., and J.G.P. Dirven. 1976. Climate, nitrogen and grass. Comparison of yield and chemical composition of some temperate and tropical grass species grown at different temperatures. Neth. J. of Agric. 24:67-78.

Demarquilly, C., and M. Niqueux. 1978. A new perennial plant for silage? Silphium perfoliatum L. Bulletin Technique, Centre de Recherches Zootechniques et Vétérinaires de Theix 34: 25-30.

Escalante-Estrada, L.E., Y.I. Escalante-Estrada, and C. Linzaga-Elizalde. 2008. Densidad de siembra del girasol forrajero. Agronomía Costarricense 32: 177-182.

Filatov, V.I., and A.I. Rudenko. 1982. Variation in yield of Heracleum sosnowskyi and Silphium perfoliatum L. with agrotechnical practices in the steppe zone of Ukraine. Izvestiya Timiryazevskoi Akademiya, im K.A. Timiryazeva, Moscow, USSR. Herb. Abstr. 53: 2.337.

Goering, H. K., and P.J. Van Soest. 1970. Forage fiber analysis (apparatus, reagents, procedures, and some applications). Agriculture Handbook $\mathrm{N}^{\circ}$ 379. ARS, USDA. Washington, D.C.

Han, K. J., K.A. Albrecht, D.R. Mertens, and D.A. Kim. 2000. Comparison of in vitro digestion kinetics of cup-plant (Silphium perfoliatum L.) and alfalfa. Asian Austral. J. Anim. Sci. 13:641-644.

Hay, R.K.M., and N.W. Offer. 1992. Helianthus tuberosus as an alternative forage crop for cool maritime regions: A preliminary study of the yield and nutritional quality of shoot tissues from perennial stands. J. Sci. Food Agric. 60:213-221.
Hay, R.K.M., and J.R. Porter. 2006. The Physiology of Crop Yield. $2^{\text {nd }}$ ed. Blackwell Publishing Company. Oxford, U.K. 328 pp.

Hodgson, J. 1990. Grazing management. Science into Practice. Longman Scientific and Technical, Essex, England. 203 pp.

Hopkins, A. 2000. Grass, its production and utilization. 3rd ed. Blackwell Science Ltd. Oxford, U.K. 440 pp.

Kosach, A.E., Chernik, V.V., and K.H. Aknazrov. 1984. Particularities of seed formation of Rhaponticum carthamoides and Silphium perfoliatum in relation to conditions of cultivation. In Ekologicheskie problemy semenovedeniya introdutsentov. Riga, Latvian USSR, 50-51. In Herb. Abstr. 1986. 56:212.

Lehmkuhler, J.W., M.H. Ramos and K.A. Albrecht. 2007. Cup-plant silage as a replacement for corn silage in growing beef cattle diets. In: Plant Management Network, November 7, 2007, Department of Agronomy, University of Wisconsin, Madison.

MAFF. 1992. Feed composition. UK tables of feed composition and nutritive value for ruminants. Ministry of Agriculture, Fisheries and Food (MAFF). 2nd ed. Chalcombe Publications. Canterbury, UK.

Matus, B.F. 1985. Formulación de un modelo matemático de arquitectura y sus relaciones con la cantidad del espacio en una población de girasol. Tesis de Ing. Agr. Pontificia Universidad Católica de Chile. Santiago, Chile. 176 pp.

Medvedev, P.F., and A. Sidorova. 1976. Yields depend on number of cuts in the preceding year. Leningradskaya Oblast', USSR. Korma 2:44. In: Herb. Abstr. 1977, 47(3).712.

Minson, D.J. 1990. Forage in ruminant nutrition. Academic Press Inc. NewYork, USA. 483 pp.

Niqueux, M. 1981. A new forage plant: Silphium perfoliatum L. Fourrages 87:119-136.

Philippi, I., J., Rodríguez, and G. Pichard. 1985. Comportamiento de diferentes genotipos de Alfalfa en andisoles ácidos. Cienc. Inv. Agr. 12 (1): 23-35.

Pichard, G., and P.J. Van Soest. 1977. Protein solubility of ruminant feeds. In: Proc. Cornell Nutrition Conference, 1-3 November, Syracuse. Department of Animal Science, Cornell University, Ithaca, New York. p. 91-98. 
Pichard, G., R., Cussen, and F. Sánchez. 1988. Silphium perfoliatum L.: un nuevo recurso forrajero de verano para la zona sur. Cien. Inv. Agr. 15: 101-106.

Schingoethe, D.J., E.W. Skyberg, and J.A. Rook. 1980. Chemical composition of sunflower silage as influenced by additions of urea, dry whey and sodium hydroxide. J. Animal Sci. 50:625-629.

Seiler, G.J. 1984. Protein and mineral concentrations of selected wild sunflower species. Agron. J. 76:289-294.

Snedecor, G.W., and W.G. Cochrane. 1967. Statistical methods. 6th Edition. The Iowa State University Press. Ames. Iowa, USA. 593 pp.

Solov'yanova, L.M. 1975. Biological characteristics of Silphium perfoliatum L. for introducing it into Sakhalin. In 8-ya konferentsiya molodykh uchenykh spetsialistov, posvyashchennaya 250-letiyu AN SSSR. Tezisy dokladov. YuzhnoSakhalinsk, USSR;. From Referativnyi Zhurnal 4.55.648. Herb. Abstr. 45(10) 3.858.

Teuber, N., F. Ortega and G. Meneses. 2008. Evaluación de nuevas líneas experimentales de trébol rosado en el sur de Chile. In: XXIII Congreso Anual de la Sociedad Chilena de Producción Animal. Octubre 2008, Valdivia, Chile. p. 81.

Trivelli, J.M. 1984. Formulación matemática de las relaciones existentes entre la cantidad, la calidad y la forma del espacio y los componentes de la arquitectura de las plantas. Tesis Ing. Agr., Pontificia Universidad Católica de Chile. 198 pp.

Utevsh, Y.A. 1976. Introduction of Silphium perfoliatum L. into cultivation. Visnik Akademii Nauk USSR. From Referativnyî Zhurnal 1.55698. Herb. Abstr. 46(9): 3.818.

Van Soest, P.J., J.B. Robertson, and B.A. Lewis. 1991. Methods for dietary fiber, neutral detergent fiber and non starch polysaccharides in relation to animal nutrition. J. Dairy Science 74:3583-3597.

Wilkins P.W., D.K., Allen, and L.R. Mytton. 2000. Differences in the nitrogen use efficiency of perennial ryegrass varieties under simulated rotational grazing and their effects on nitrogen recovery and herbage nitrogen content. Grass and Forage Science 55: 69-76. 
